\title{
Impact of Leadership Style to Financial Performance of Enterprises
}

\section{Ivan Miloloža}

Faculty for Dental Medicine \& Health, University of Osijek, Osijek, Croatia

\section{Abstract}

Background: Measurement of financial performance of enterprises is an important part of balanced scorecard system. Previous research has indicated a relationship between leadership and financial performance of enterprises. Objectives: Purpose of the paper is to investigate the impact of leadership styles in Croatian enterprises to their financial performance. Methods/Approach: Survey research has been conducted on the sample of Croatian companies, measuring their financial performance and presence of leadership styles. Results: Overall, democratic style is the most often present in Croatian enterprises, followed by the authoritarian and laissez-faire styles. Conclusions: Small enterprises are more successful financially in the presence of the democratic style. Enterprises in the stagnation phase are more successful if all leadership styles are mixed together in practice, indicating the need to push the employees with all possible styles. Enterprises oriented towards international markets are more successful financially in the presence of the democratic style and the laissez-faire style.

Keywords: financial performance, leadership styles, democratic, authoritarian, laissez-faire, international, SME, enterprise

JEL classification: 015

Paper type: Research article

Received: Feb 07, 2018

Accepted: Feb 14, 2018

Citation: Miloloža, I. (2018), "Impact of Leadership Style to Financial Performance of Enterprises", Business Systems Research, Vol. 9, No. 1, pp. 93-106.

DOI: 10.2478/bsrj-2018-0008

\section{Introduction}

The financial perspective includes indicators that are related to the enterprise strategy (Westerfield, 2003; Parast et al., 2015). In other words, measuring financial performance will show how the implementation of the strategy contributes to the creation of final results. The objectives of the financial perspective should bring about positive results, which affects the results of other perspectives (Kang et al., 2014). In addition, it is important to keep track of the financial perspective and balance it with other non-financial perspectives. The focus of the enterprise on managing relations with customers, suppliers and partners, or on quality of products, must be aligned with other financial indicators and must impact them positively, which is true for any other business indicator as well (Kovach et al., 2015). 
The main goal of the financial perspective is to increase the shareholder value, which can be achieved in two ways. The first way is to increase revenue. The steps leading to the achievement of the first goal are: emergence on new markets, offering new products and attracting new customers. The other way is to increase productivity, which can be achieved by improving costs structure or by utilizing existing assets better through the reduction of capital required to support a determined business level (Eljelly, 2004). It is important to point out that both ways which lead to increase in the shareholder value must be carried out actively and simultaneously. That way it is possible to eliminate the risk of endangering the growth of the enterprise.

Leading and leadership are two different terms that cannot be used interchangeably. Leadership can be defined by personal traits or as a process. Leading is one of the five management functions, and according to some scientists also the most important one, because it is focused on working with people, harmonising their relationships and encouraging them to work and perform tasks more efficiently. Leading consists of a set of processes that direct employees towards achieving goals more efficiently (Pejic Bach et al., 2006; 2013).

Successful leadership represents one of the most important factors that contribute to the enterprise success, and it can be defined in several ways that will be hereinafter set out. Koontz et al. (1990) define leadership as a process of influencing employees in order to motivate and encourage them to achieve the enterprise's goals. Griffin (2002) believes that leadership is both a process and a trait. As a process, leadership represents the focus on activities that a leader takes, and as a trait, leadership represents leader's traits. Leadership can also be defined as the skill of encouraging employees to participate voluntarily in the realization of enterprise's goals (Rožman et al., 2017).

Previous research has shown that leadership styles have a different impact on the success of an enterprise in the knowledge management area (Miloža 2015a, 2015b, $2015 \mathrm{c}$ ). The contribution of this research will be to determine the impact of leadership styles on the financial success of an enterprise.

\section{Literature review}

\section{Measuring financial success}

There is a large number of the financial success measurements and only one measurement cannot lead to a financial result, thus it is important to use multiple measurements at the same time. The three most commonly used financial measurements are: (i) business growth, (ii) value creation and (iii) business profitability. Financial measurement Business growth includes: revenue to assets ratio, increase in revenue and assets, revenue from new products and services, as well as revenue per employee. Financial measurement Value creation includes: economic value added (EVA), market value added (MVA), stock price and dividends. Financial measurement Business profitability includes: profit margin, ROE, ROA, ROI, ROCE and profit per employee.

Financial perspective usually involves indicators that include revenue to costs ratio, return on investment (ROI), return on equity (ROE) and economic value added (EVA). Depending on the industry within which an enterprise operates, it is possible to use indicators such as risk management or measuring intellectual capital. Indicators from the financial perspective are a prerequisite for selecting other indicators, thus they need to be defined very carefully. 
There is a large number of financial indicators, and the most commonly used ones are as follows (Niven, 2007): total assets, ratio of profit to assets, return on net assests, gross margin, net operating profit after taxes, profit per employee, revenue from new products, revenue and revenue per employee, return on equity (ROE), return on capital employed (ROCE), return on investment (ROI), economic value added (EVA), cash flow, debt indicators, interest coverage ratio, accounts receivable collection period, period of obligations to suppliers, current ratio. In small and medium-sized enterprises in Croatia, the most commonly used financial indicators are liquidity indicators and indicators of accounts receivable collection period.

Parmenter (2010) states the following measurements in order to manage the financial perspective successfully: (i) total assets and total assets per employee, (ii) return on equity (ROE) and return on capital employed (ROCE), (iii) economic value added (EVA), (iv) value added per employee, (v) gross margin, (vi) growth rate, (vii) credit rating, (viii) debt, (ix) dividends and stock price.

\section{Measuring leadership styles}

Scientists who supported behaviour-based leadership theories tried to define the best leadership style that would be effective in all situations, which led to several theories and leadership models such as: authoritarian, democratic and laissez-faire leadership style. Given the advantages and disadvantages that exist in all three leadership styles, one can conclude that there is no single best leadership style, but that leaders must adapt to the situation and their associates in order to achieve the best result.

\section{Methodology}

The Leadership Styles Questionnaire, taken from the book Introduction to Leadership by Northouse (2012) was used as a research instrument. In addition, a questionnaire for measuring enterprise success in terms of four dimensions of success was used. Table 1 shows the financial success of all enterprises together. It can be noticed that respondents from all enterprises believe that items F1. Profitability, F2. Profit and F3. Return on investment within dimension Financial success are equally important (average rating 3.50). Cronbach's alpha is greater than 0.7 , which indicates that the financial success indicators are consistent.

Table 1

Financial success of all enterprises together

\begin{tabular}{llllrrr}
\hline & N & Min & Max & Average & St. dev. & Cronbach's alpha \\
\hline Financial success & \multicolumn{7}{c}{} & & & & & \\
F1. Profitability & 60 & 2 & 5 & 3.533 & 0.833 & 0.825 \\
F2. Profit & 60 & 2 & 5 & 3.500 & 0.893 & \\
\hline F3. Return on investment & 60 & 2 & 5 & 3.517 & 0.930 & \\
\hline
\end{tabular}

Source: Authors' work

The survey was conducted on a stratified sample of 60 Croatian enterprises total divided into 6 sub-groups. Of this, there were: (1) 10 small and medium-sized enterprises in the growth phase (sub-code: SME-growth); (2) 10 small and mediumsized enterprises in the maturity phase (sub-code: SME-maturity); (3) 10 small and medium-sized enterprises in the stagnation phase (sub-code: SME-stagnation); (4) 10 large enterprises in the growth phase (sub-code: Large-growth); (5) 10 large 
enterprises in the maturity phase (sub-code: Large-maturity) and (6) 10 large enterprises in the stagnation phase (sub-code: Large-stagnation).

Comparison of average ratings of the presence of leadership styles in all enterprises together is as follows. The respondents agree mostly with the attitudes that reflect democratic leadership style, while they agree the least with the attitudes that reflect laissez-faire leadership style (the lowest average ratings are recorded).

\section{Results}

\section{Impact of leadership styles on all enterprises together}

Table 2 shows a regression model with the dependent variable Financial success. All items of measuring leadership styles, which refer to the authoritarian, democratic and laissez-faire style, were used as independent variables. Step-wise multiple regression analysis was used to form the model. A model with a determination coefficient of 0.254 was established, indicating that the selected model implied $25.4 \%$ deviation from the dependent variable.

There is only one statistically significant independent variable in the model that reflects the authoritarian style - L10. Most employees feel insecure about their work and need direction (statistically significant at $1 \%$ level). Variable L 10 has a negative impact on the dependent variable Financial success in all enterprises.

There is one statistically significant independent variable in the model that reflects the democratic style - L14. It is the leader's job to help subordinates find their "passion" (statistically significant at 1\% level). Variable L14 has a positive impact on the dependent variable Financial success in all enterprises.

There is only one statistically significant independent variable in the model that reflects the laissez-faire style - L15. In most situations, workers prefer little input from the leader (statistically significant at $1 \%$ level). Variable $\mathrm{L} 15$ has a positive impact on the dependent variable Financial success in all enterprises.

Table 2

Regression model with the dependent variable: Financial success and the independent variables: items of leadership styles - all enterprises together

\begin{tabular}{|c|c|c|c|c|c|}
\hline Financial success & $\begin{array}{l}\text { Non-stand. } \\
\text { coefficients }\end{array}$ & $\begin{array}{l}\text { Standard } \\
\text { error }\end{array}$ & $\begin{array}{l}\text { Standardized } \\
\text { coefficients }\end{array}$ & $t$ & P-value \\
\hline Constant & 2.403 & 0.405 & & 5.936 & $0.000^{* * *}$ \\
\hline \multicolumn{6}{|l|}{ Authoritarian style } \\
\hline $\begin{array}{l}\text { L 10. Most employees feel } \\
\text { insecure about their work and } \\
\text { need direction. }\end{array}$ & -0.271 & 0.089 & -0.393 & -3.038 & $0.004^{* * *}$ \\
\hline \multicolumn{6}{|l|}{ Democratic style } \\
\hline $\begin{array}{l}\text { L 14. It is the leader's job to } \\
\text { help subordinates find their } \\
\text { "passion". }\end{array}$ & .0 .322 & 0.105 & 0.375 & 3.058 & $0.003^{* * *}$ \\
\hline \multicolumn{6}{|l|}{ Laissez-faire style } \\
\hline $\begin{array}{l}\text { L 15. In most situations. workers } \\
\text { prefer little input from the } \\
\text { leader. }\end{array}$ & 0.264 & 0.087 & 0.371 & 3.043 & $0.004^{* * *}$ \\
\hline \multicolumn{6}{|l|}{ Model fit } \\
\hline R2 & & & & & 0.254 \\
\hline Adjusted R2 & & & & & 0.214 \\
\hline
\end{tabular}




\section{Impact of leadership styles on small and medium-sized enterprises}

Table 3 shows a regression model with the dependent variable Financial success in SME enterprises. All items of measuring leadership styles, which refer to the authoritarian, democratic and laissez-faire style, were used as independent variables. Step-wise multiple regression analysis was used to form the model. A model with a determination coefficient of 0.420 was established, indicating that the selected model implied $42.0 \%$ deviation from the dependent variable.

There are two statistically significant independent variables in the model that reflect the authoritarian style - L10. Most employees feel insecure about their work and need direction (statistically significant at 5\% level) and L13. The leader is the chief judge of the achievements of the members of the group (statistically significant at $5 \%$ level). Variable $\mathrm{L} 10$ has a negative impact on the dependent variable Financial success in SME enterprises, while variable L 13 has a positive impact.

There is only one statistically significant independent variable in the model that reflects the democratic style - L8. Most workers want frequent and supportive communication from their leader (statistically significant at $5 \%$ level). Variable 28 has a positive impact on the dependent variable Financial success in SME enterprises.

There is only one statistically significant independent variable in the model that reflects the laissez-faire - L15. In most situations, workers prefer little input from the leader (statistically significant at $1 \%$ level). Variable L 15 has a positive impact on the dependent variable Financial success in SME enterprises.

\section{Table 3}

Regression model with the dependent variable: Financial success and the independent variables: items of leadership styles in relation to the size of the enterprise - SME

\begin{tabular}{|c|c|c|c|c|c|}
\hline Financial success - SME & $\begin{array}{l}\text { Non-stand. } \\
\text { coefficients }\end{array}$ & $\begin{array}{l}\text { Standard } \\
\text { error }\end{array}$ & $\begin{array}{l}\text { Standardized } \\
\text { coefficients }\end{array}$ & $t$ & P-value \\
\hline Constant & 0.096 & 1.240 & & 0.077 & 0.939 \\
\hline \multicolumn{6}{|l|}{ Authoritarian style } \\
\hline $\begin{array}{l}\text { L } 10 . \text { Most employees feel } \\
\text { insecure about their work } \\
\text { and need direction. }\end{array}$ & -0.293 & 0.107 & -0.444 & -2.744 & $0.011^{* *}$ \\
\hline $\begin{array}{l}\text { L 13. The leader is the } \\
\text { chief judge of the } \\
\text { achievements of the } \\
\text { members of the group. }\end{array}$ & 0.321 & 0.152 & 0.328 & 2.113 & $0.045^{* *}$ \\
\hline \multicolumn{6}{|l|}{ Democratic style } \\
\hline $\begin{array}{l}\text { L } 8 \text {. Most workers want } \\
\text { frequent and supportive } \\
\text { communication from their } \\
\text { leader. }\end{array}$ & 0.369 & 0.197 & 0.314 & 1.871 & $0.073^{*}$ \\
\hline \multicolumn{6}{|l|}{ Laissez-faire style } \\
\hline $\begin{array}{l}\text { L 15. In most situations. } \\
\text { workers prefer little input } \\
\text { from the leader. }\end{array}$ & 0.392 & 0.118 & 0.588 & 3.335 & $0.003^{* * *}$ \\
\hline \multicolumn{6}{|l|}{ Model fit } \\
\hline R2 & & & & & 0.420 \\
\hline Adjusted R2 & & & & & 0.327 \\
\hline
\end{tabular}




\section{Impact of leadership styles on large enterprises}

Table 4 shows a regression model with the dependent variable Financial success. All items of measuring leadership styles, which refer to the authoritarian, democratic and laissez-faire style, were used as independent variables. Step-wise multiple regression analysis was used to form the model. A model with a determination coefficient of 0.563 was established, indicating that the selected model implied $56.3 \%$ deviation from the dependent variable.

There are two statistically significant independent variables in the model that reflect the authoritarian style - L13. The leader is the chief judge of the achievements of the members of the group (statistically significant at $10 \%$ level) and L16. Effective leaders give orders and clarify procedures (statistically significant at $10 \%$ level). Variable L13 has a positive impact on the dependent variable Financial success in large enterprises, while variable L16 has a negative impact.

There are two statistically significant independent variables in the model that reflect the democratic style - L11. Leaders need to help subordinates accept responsibility for completing their work (statistically significant at $5 \%$ level) and L14. It is the leader's job to help subordinates find their "passion" (statistically significant at $1 \%$ level). Variable L11 has a negative impact on the dependent variable Financial success in large enterprises, while variable L14 has a positive impact.

There are two statistically significant independent variables in the model that reflect the laissez-faire style - L6. Leadership requires staying out of the way of subordinates as they do their work (statistically significant at $1 \%$ level) and L15. In most situations, workers prefer little input from the leader (statistically significant at $1 \%$ level). Variable $\mathrm{L6}$ has a negative impact on the dependent variable Financial success in large enterprises, while variable L 15 has a positive impact.

\section{Table 4}

Regression model with the dependent variable: Financial success and the independent variables: items of leadership styles - large enterprises

\begin{tabular}{|c|c|c|c|c|c|}
\hline Financial success - Large & $\begin{array}{l}\text { Non-stand. } \\
\text { coefficients }\end{array}$ & $\begin{array}{c}\text { Standard } \\
\text { error }\end{array}$ & $\begin{array}{l}\text { Standardized } \\
\text { coefficients }\end{array}$ & $t$ & P-value \\
\hline Constant & 2.459 & 0.921 & & 2.671 & $0.014^{* *}$ \\
\hline \multicolumn{6}{|l|}{ Authoritarian style } \\
\hline $\begin{array}{l}\mathrm{L} 13 . \text { The leader is the chief judge of } \\
\text { the achievements of the members of } \\
\text { the group. }\end{array}$ & 0.332 & 0.162 & 0.347 & 2.045 & $0.052^{*}$ \\
\hline $\begin{array}{l}\text { L 16. Effective leaders give orders and } \\
\text { clarify procedures. }\end{array}$ & -0.162 & 0.079 & -0.328 & -2.062 & $0.051^{*}$ \\
\hline \multicolumn{6}{|l|}{ Democratic style } \\
\hline $\begin{array}{l}\text { L 11. Leaders need to help } \\
\text { subordinates accept responsibility for } \\
\text { completing their work. }\end{array}$ & -0.326 & 0.154 & -0.390 & -2.121 & $0.045^{* *}$ \\
\hline $\begin{array}{l}\text { L 14. It is the leader's job to help } \\
\text { subordinates find their "passion". }\end{array}$ & 0.450 & 0.128 & 0.571 & 3.520 & $0.002^{* * *}$ \\
\hline \multicolumn{6}{|l|}{ Laissez-faire style } \\
\hline $\begin{array}{l}\text { L 6. Leadership requires staying out of } \\
\text { the way of subordinates as they do } \\
\text { their work. }\end{array}$ & -0.325 & 0.106 & -0.472 & -3.061 & $0.006 * * *$ \\
\hline $\begin{array}{l}\text { L 15. In most situations. workers prefer } \\
\text { little input from the leader. }\end{array}$ & 0.425 & 0.121 & 0.506 & 3.507 & $0.002^{* * *}$ \\
\hline \multicolumn{6}{|l|}{ Model fit } \\
\hline R2 & & & & & 0.563 \\
\hline Adjusted R2 & & & & & 0.449 \\
\hline
\end{tabular}

Note: $* 10 \%, * * 5 \%, * * * 1 \%$ probability

Source: Authors' work 


\section{Impact of leadership styles on enterprises in the growth and maturity phase (leaders)}

Table 5 shows a regression model with the dependent variable Financial success in enterprises in the growth and maturity phase (leaders). All items of measuring leadership styles, which refer to the authoritarian, democratic and laissez-faire style, were used as independent variables. Step-wise multiple regression analysis was used to form the model. A model with a determination coefficient of 0.407 was established, indicating that the selected model implied $40.7 \%$ deviation from the dependent variable.

There is only one statistically significant independent variable in the model that reflects the authoritarian style - L16. Effective leaders give orders and clarify procedures (statistically significant at $5 \%$ level). Variable L 16 has a negative impact on the dependent variable Financial success in market leader enterprises.

There are three statistically significant independent variables in the model that reflect the laissez-faire style - L12. Leaders should give subordinates complete freedom to solve problems on their own (statistically significant at $5 \%$ level), L 15. In most situations, workers prefer little input from the leader (statistically significant at $10 \%$ level) and L18. In general, it is best to leave subordinates alone (statistically significant at $1 \%$ level). Variable L15 has a positive impact on the dependent variable Financial success in market leader enterprises, while variables L12 and L18 have a negative impact.

\section{Table 5}

Regression model with the dependent variable: Financial success and the independent variables: items of leadership styles in relation to the growth phase of the enterprise - Enterprises in the growth and maturity phase (leaders)

\begin{tabular}{|c|c|c|c|c|c|}
\hline $\begin{array}{l}\text { Financial success - } \\
\text { Enterprises in the growth and } \\
\text { maturity phase (leaders) }\end{array}$ & $\begin{array}{l}\text { Non-stand. } \\
\text { coefficients }\end{array}$ & $\begin{array}{l}\text { Standard } \\
\text { error }\end{array}$ & $\begin{array}{l}\text { Standardized } \\
\text { coefficients }\end{array}$ & $t$ & P-value \\
\hline Constant & 4.146 & 0.537 & & 7.728 & $0.000^{* * *}$ \\
\hline \multicolumn{6}{|l|}{ Authoritarian style } \\
\hline $\begin{array}{l}\text { L 16. Effective leaders give } \\
\text { orders and clarify procedures. }\end{array}$ & -0.143 & 0.078 & -0.265 & -1.849 & $0.074^{* *}$ \\
\hline \multicolumn{6}{|l|}{ Laissez-faire style } \\
\hline $\begin{array}{l}\text { L 12. Leaders should give } \\
\text { subordinates complete freedom } \\
\text { to solve problems on their own. }\end{array}$ & -0.182 & 0.096 & -0.276 & -1.901 & $0.067^{*}$ \\
\hline $\begin{array}{l}\text { L 15. In most situations. workers } \\
\text { prefer little input from the } \\
\text { leader. }\end{array}$ & 0.372 & 0.108 & 0.494 & 3.444 & $0.002^{* * *}$ \\
\hline $\begin{array}{l}\text { L 18. In general. it is best to } \\
\text { leave subordinates alone. }\end{array}$ & -0.195 & 0.099 & -0.289 & -1.962 & $0.059 *$ \\
\hline \multicolumn{6}{|l|}{ Model fit } \\
\hline R2 & & & & & 0.407 \\
\hline Adjusted R2 & & & & & 0.331 \\
\hline
\end{tabular}




\section{Impact of leadership styles on enterprises in the stagnation phase (followers)}

Table 6

Regression model with the dependent variable: Financial success and the independent variables: items of leadership styles in relation the growth phase of the enterprise - Enterprises in the stagnation phase (followers)

\begin{tabular}{|c|c|c|c|c|c|}
\hline $\begin{array}{l}\text { Financial success - } \\
\text { Enterprises in the stagnation } \\
\text { phase (followers) }\end{array}$ & $\begin{array}{l}\text { Non-stand. } \\
\text { coefficients }\end{array}$ & $\begin{array}{l}\text { Standard } \\
\text { error }\end{array}$ & $\begin{array}{l}\text { Standardized } \\
\text { coefficients }\end{array}$ & $t$ & P-value \\
\hline Constant & -2.146 & 0.808 & & -2.657 & $0.017^{* *}$ \\
\hline \multicolumn{6}{|l|}{ Authoritarian style } \\
\hline $\begin{array}{l}\text { L 7. As a rule. employees } \\
\text { must be given rewards or } \\
\text { punishments in order to } \\
\text { motivate them to achieve } \\
\text { organizational objectives. }\end{array}$ & 0.315 & 0.084 & 0.407 & 3.734 & $0.002^{* * *}$ \\
\hline $\begin{array}{l}\text { L 10. Most employees feel } \\
\text { insecure about their work } \\
\text { and need direction. }\end{array}$ & -0.278 & 0.075 & -0.404 & -3.696 & $0.002^{* * *}$ \\
\hline $\begin{array}{l}\text { L 13. The leader is the chief } \\
\text { judge of the achievements } \\
\text { of the members of the } \\
\text { group. }\end{array}$ & 0.680 & 0.109 & 0.740 & 6.257 & $0.000^{* * *}$ \\
\hline \multicolumn{6}{|l|}{ Democratic style } \\
\hline $\begin{array}{l}\text { L 8. Most workers want } \\
\text { frequent and supportive } \\
\text { communication from their } \\
\text { leader. }\end{array}$ & 0.273 & 0.132 & 0.218 & 2.068 & $0.055^{*}$ \\
\hline \multicolumn{6}{|l|}{ Laissez-faire style } \\
\hline $\begin{array}{l}\text { L 3. In complex situations. } \\
\text { leaders should let } \\
\text { subordinates work } \\
\text { problems out on their own. }\end{array}$ & 0.257 & 0.071 & 0.407 & 3.601 & $0.002^{* * *}$ \\
\hline $\begin{array}{l}\text { L 6. Leadership requires } \\
\text { staying out of the way of } \\
\text { subordinates as they do } \\
\text { their work. }\end{array}$ & -0.176 & 0.085 & -0.227 & -2.062 & $0.056^{*}$ \\
\hline $\begin{array}{l}\text { L 15. In most situations. } \\
\text { workers prefer little input } \\
\text { from the leader. } \\
\text { Model fit }\end{array}$ & 0.301 & 0.072 & 0.445 & 4.160 & $0.001^{* * *}$ \\
\hline R2 & & & & & 0.843 \\
\hline Adjusted R2 & & & & & 0.774 \\
\hline
\end{tabular}

Table 6 shows a regression model with the dependent variable Financial success in enterprises in the stagnation phase (followers). All items of measuring leadership styles, which refer to the authoritarian, democratic and laissez-faire style, were used as independent variables. Step-wise multiple regression analysis was used to form the model. A model with a determination coefficient of 0.843 was established, indicating that the selected model implied $84.3 \%$ deviation from the dependent variable. 
There are three statistically significant independent variables in the model that reflect the authoritarian style - L7. As a rule, employees must be given rewards or punishments in order to motivate them to achieve organizational objectives (statistically significant at 1\% level), L10. Most employees feel insecure about their work and need direction (statistically significant at $1 \%$ level) and L13. The leader is the chief judge of the achievements of the members of the group (statistically significant at $1 \%$ level). Variables L7 and L13 have a positive impact on the dependent variable Financial success in market follower enterprises, while variable L10 has a negative impact.

There is only one statistically significant independent variable in the model that reflects the democratic style - L8. Most workers want frequent and supportive communication from their leader (statistically significant at $10 \%$ level). Variable L8 has a positive impact on the dependent variable Financial success in market follower enterprises.

There are three statistically significant independent variables in the model that reflect the laissez-faire style - L3. In complex situations, leaders should let subordinates work problems out on their own (statistically significant at $1 \%$ level), L6. Leadership requires staying out of the way of subordinates as they do their work (statistically significant at 10\% level) and L15. In most situations, workers prefer little input from the leader (statistically significant at 1\% level). Variables L3 and L15 have a positive impact on the dependent variable financial success in market follower enterprises, while variable L6 has a negative impact

\section{Impact of leadership styles on enterprises oriented towards domicile markets}

Table 7 shows a regression model with the dependent variable Financial success in enterprises oriented predominantly towards domestic market. All items of measuring leadership styles, which refer to the authoritarian, democratic and laissez-faire style, were used as independent variables. Step-wise multiple regression analysis was used to form the model. A model with a determination coefficient of 0.456 was established, indicating that the selected model implied $45.6 \%$ deviation from the dependent variable.

There is only one statistically significant independent variable in the model that reflects the authoritarian style - L10. Most employees feel insecure about their work and need direction (statistically significant at $5 \%$ level). Variable L 10 has a negative impact on the dependent variable Financial success in enterprises oriented predominantly towards domestic market.

There are two statistically significant independent variables in the model that reflect the democratic style - L14. It is the leader's job to help subordinates find their "passion" (statistically significant at 5\% level) and L17. People are basically competent and if given a task will do a good job (statistically significant at $10 \%$ level). Variable L14 has a positive impact on the dependent variable Financial success in enterprises oriented predominantly towards domestic market, while variable L17 has a negative impact.

There are two statistically significant independent variables in the model that reflect the laissez-faire style - L 15. In most situations, workers prefer little input from the leader (statistically significant at $1 \%$ level) and L18. In general, it is best to leave subordinates alone (statistically significant at $10 \%$ level). Variable L18 has a negative impact on the dependent variable Financial success in enterprises oriented predominantly towards domestic market, while variable L 15 has a positive impact. 


\section{Table 7}

Regression model with the dependent variable: Financial success and the independent variables: items of leadership styles in relation to the international orientation of the enterprise - Predominantly domestic market

\begin{tabular}{|c|c|c|c|c|c|}
\hline $\begin{array}{l}\text { Financial success - Predominantly } \\
\text { domestic market }\end{array}$ & $\begin{array}{l}\text { Non-stand. } \\
\text { coefficients }\end{array}$ & $\begin{array}{l}\text { Standard } \\
\text { error }\end{array}$ & $\begin{array}{l}\text { Standardized } \\
\text { coefficients }\end{array}$ & $t$ & P-value \\
\hline Constant & 3.890 & 0.584 & & 6.666 & $0.000^{* * *}$ \\
\hline \multicolumn{6}{|l|}{ Authoritarian style } \\
\hline $\begin{array}{l}\text { L } 10 . \text { Most employees feel insecure } \\
\text { about their work and need } \\
\text { direction. }\end{array}$ & -0.265 & 0.109 & -0.387 & -2.447 & $0.020 * *$ \\
\hline \multicolumn{6}{|l|}{ Democratic style } \\
\hline $\begin{array}{l}\text { L 14. It is the leader's job to help } \\
\text { subordinates find their "passion". }\end{array}$ & 0.258 & 0.119 & 0.326 & 2.164 & $0.038^{* *}$ \\
\hline $\begin{array}{l}\text { L 17. People are basically } \\
\text { competent and if given a task will } \\
\text { do a good job. }\end{array}$ & -0.235 & 0.116 & -0.280 & -2.024 & $0.051^{*}$ \\
\hline \multicolumn{6}{|l|}{ Laissez-faire style } \\
\hline $\begin{array}{l}\text { L 15. In most situations. workers } \\
\text { prefer little input from the leader. }\end{array}$ & 0.355 & 0.090 & 0.546 & 3.918 & $0.000^{* * *}$ \\
\hline $\begin{array}{l}\text { L } 18 \text {. In general. it is best to leave } \\
\text { subordinates alone. }\end{array}$ & -0.221 & 0.109 & -0.284 & -2.018 & $0.052^{*}$ \\
\hline \multicolumn{6}{|l|}{ Model fit } \\
\hline R2 & & & & & 0.456 \\
\hline Adjusted R2 & & & & & 0.371 \\
\hline
\end{tabular}

\section{Impact of leadership styles on enterprises oriented towards} international markets

Table 8 shows a regression model with the dependent variable Financial success in enterprises oriented predominantly towards foreign market. All items of measuring leadership styles, which refer to the authoritarian, democratic and laissez-faire style, were used as independent variables. Step-wise multiple regression analysis was used to form the model. A model with a determination coefficient of 0.926 was established, indicating that the selected model implied $92.6 \%$ deviation from the dependent variable.

There are two statistically significant independent variables in the model that reflect the authoritarian style - L4. It is fair to say that most employees in the general population are lazy (statistically significant at $1 \%$ level) and L10. Most employees feel insecure about their work and need direction (statistically significant at $1 \%$ level). Variable L4 has a positive impact on the dependent variable Financial success in enterprises oriented predominantly towards foreign market, while variable L 10 has a negative impact.

There are three statistically significant independent variables in the model that reflect the democratic style - L2. Employees want to be a part of the decisionmaking process (statistically significant at $1 \%$ level), L14. It is the leader's job to help subordinates find their "passion" (statistically significant at 1\% level) and L17. People are basically competent and if given a task will do a good job (statistically significant at $1 \%$ level). Variables L2, L14 and L17 have a positive impact on the dependent variable Financial success in enterprises oriented predominantly towards foreign market. 
There are three statistically significant independent variables in the model that reflect the laissez-faire style - L3. In complex situations, leaders should let subordinates work problems out on their own (statistically significant at $1 \%$ level), $L 6$. Leadership requires staying out of the way of subordinates as they do their work (statistically significant at $1 \%$ level) and L15. In most situations, workers prefer little input from the leader (statistically significant at $5 \%$ level). Variable $L 6$ has a positive impact on the dependent variable Financial success in enterprises oriented predominantly towards foreign market, while variables L3 and L15 have a positive impact.

\section{Table 8}

Regression model with the dependent variable: Financial success and the independent variables: items of leadership styles in relation to the international orientation of the enterprise - Predominantly foreign market

\begin{tabular}{|c|c|c|c|c|c|}
\hline $\begin{array}{l}\text { Financial success - } \\
\text { Predominantly foreign market }\end{array}$ & $\begin{array}{l}\text { Non-stand. } \\
\text { coefficients }\end{array}$ & $\begin{array}{l}\text { Standard } \\
\text { error }\end{array}$ & $\begin{array}{l}\text { Standardized } \\
\text { coefficients }\end{array}$ & $t$ & P-value \\
\hline Constant & -3.910 & 1.278 & & -3.061 & $0.009^{* * *}$ \\
\hline \multicolumn{6}{|l|}{ Authoritarian style } \\
\hline $\begin{array}{l}\text { L } 4 \text {. It is fair to say that most } \\
\text { employees in the general } \\
\text { population are lazy. }\end{array}$ & 0.395 & 0.120 & 0.443 & 3.292 & $0.006^{* * *}$ \\
\hline $\begin{array}{l}\text { L 10. Most employees feel } \\
\text { insecure about their work and } \\
\text { need direction. }\end{array}$ & -0.199 & 0.063 & -0.280 & -3.142 & $0.008^{* * *}$ \\
\hline \multicolumn{6}{|l|}{ Democratic style } \\
\hline $\begin{array}{l}\text { L 2. Employees want to be a } \\
\text { part of the decision-making } \\
\text { process. }\end{array}$ & 0.521 & 0.123 & 0.512 & 4.252 & $0.001^{* * *}$ \\
\hline $\begin{array}{l}\text { L 14. It is the leader's job to } \\
\text { help subordinates find their } \\
\text { "passion". }\end{array}$ & 0.603 & 0.098 & 0.585 & 6.145 & $0.000^{* * *}$ \\
\hline $\begin{array}{l}\text { L 17. People are basically } \\
\text { competent and if given a task } \\
\text { will do a good job. }\end{array}$ & 0.811 & 0.142 & 0.840 & 5.702 & $0.000 * * *$ \\
\hline \multicolumn{6}{|l|}{ Laissez-faire style } \\
\hline $\begin{array}{l}\text { L } 3 . \text { In complex situations. } \\
\text { leaders should let subordinates } \\
\text { work problems out on their } \\
\text { own. }\end{array}$ & 0.449 & 0.063 & 0.764 & 7.132 & $0.000^{* * *}$ \\
\hline $\begin{array}{l}\text { L 6. Leadership requires } \\
\text { staying out of the way of } \\
\text { subordinates as they do their } \\
\text { work. }\end{array}$ & -0.548 & 0.074 & -0.658 & -7.369 & $0.000^{* * *}$ \\
\hline $\begin{array}{l}\text { L 15. In most situations. workers } \\
\text { prefer little input from the } \\
\text { leader. }\end{array}$ & 0.249 & 0.101 & 0.271 & 2.471 & $0.028^{* *}$ \\
\hline \multicolumn{6}{|l|}{ Model fit } \\
\hline R2 & & & & & 0.926 \\
\hline Prilagođeni R2 & & & & & 0.880 \\
\hline
\end{tabular}

Source: Authors' work

\section{Discussion}

Table 9 shows the impact of different leadership styles on the aggregate financial success variable. The last three lines of the table show the dominant impact of a particular leadership style. 


\section{Table 9}

Impact of different leadership styles on the aggregate variable of financial success

\begin{tabular}{|c|c|c|c|c|c|c|c|}
\hline All together & All & SME & Large & $\begin{array}{l}\text { Growth and } \\
\text { maturity phase } \\
\text { (leaders) }\end{array}$ & $\begin{array}{c}\text { Stagnation } \\
\text { phase } \\
\text { (followers) }\end{array}$ & International & Domicile \\
\hline \multicolumn{8}{|l|}{ L1 } \\
\hline L4 & & & & & & $1 \%$ & \\
\hline L7 & & & & & $1 \%$ & & \\
\hline L10 & $-1 \%$ & $-1 \%$ & & & $-1 \%$ & $-1 \%$ & $-5 \%$ \\
\hline L13 & & $5 \%$ & $10 \%$ & & $1 \%$ & & \\
\hline L16 & & & $-10 \%$ & $-10 \%$ & & & \\
\hline L2 & & & & & & $1 \%$ & \\
\hline \multicolumn{8}{|l|}{ L5 } \\
\hline L8 & & & & & $10 \%$ & & \\
\hline L11 & & $10 \%$ & $-1 \%$ & & & & \\
\hline L14 & $1 \%$ & & $1 \%$ & & & $1 \%$ & $5 \%$ \\
\hline L17 & & & & & & $1 \%$ & $-10 \%$ \\
\hline L3 & & & & & $1 \%$ & $1 \%$ & \\
\hline L6 & & & $-1 \%$ & & $-10 \%$ & $-1 \%$ & \\
\hline \multicolumn{8}{|l|}{ L9 } \\
\hline L12 & & & & $-10 \%$ & & & \\
\hline L15 & $1 \%$ & $1 \%$ & $1 \%$ & $1 \%$ & $1 \%$ & $1 \%$ & $1 \%$ \\
\hline L18 & & & & $-10 \%$ & & & $-10 \%$ \\
\hline Authoritarian & - & $\varnothing$ & $\varnothing$ & - & + & $\varnothing$ & - \\
\hline Democratic & + & + & $\varnothing$ & $\varnothing$ & + & + & $\varnothing$ \\
\hline Laissez-faire & + & + & $\varnothing$ & - & 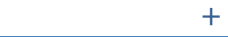 & + & $\varnothing$ \\
\hline
\end{tabular}

\section{Authoritarian leadership style}

It can be noticed that variable $L 4$ has a statistically significant positive impact on the financial success only in enterprises oriented towards international market, and the same goes for variable L7 and enterprises in the stagnation phase (followers). On the other hand, only variable L10 has a negative impact on virtually all enterprises, except on large enterprises and enterprises in the growth and maturity phase.

\section{Democratic leadership style}

It can be noticed that the variables related to the democratic leadership style have almost entirely positive impact on both large and small enterprises, both market leaders and followers, and regardless of the market orientation. It is possible to single out variable L14, which has a statistically significant positive impact on the financial success in both small and large enterprises, as well as in both enterprises oriented towards international market and enterprises oriented towards domestic market. On the other hand, only two variables have a negative impact on the aggregate variable of financial success. Variable $L 11$ has a negative impact on large enterprises, while variable L 17 has a negative impact on enterprises oriented towards domestic market.

\section{Laissez-faire leadership style}

It can be noticed that variable L 15 has a statistically significant positive impact on the aggregate variable of financial success in all enterprises, regardless of their size, market orientation or growth phase, and the same goes for variable L3 and 
enterprises in the stagnation phase (followers) and enterprises oriented towards international market. On the other hand, variable L6 has a negative impact on large enterprises, enterprises in the stagnation phase, as well as enterprises oriented towards international market, which is also true for variable L18 and enterprises in the growth and maturity phase (leaders) and enterprises oriented towards domestic market.

\section{Conclusion}

The research results point to the following differences in financial success. For the purpose of the conclusion, only the difference in the aggregate variable of financial success will be analysed. The influence of the authoritarian style is as follows: (i) a negative impact is present in enterprises in the growth and maturity phase, as well as in enterprises oriented predominantly towards domicile markets; (ii) a neutral impact is present in small, medium-sized and large enterprises, in enterprises in the stagnation phase, as well as in enterprises oriented towards international markets; (iii) a positive impact is not present in any enterprise group. The impact of the democratic style is as follows: (i) a negative impact is not present in any enterprise group; (ii) a neutral impact is present in large enterprises and enterprises oriented towards domicile market; (iii) a positive impact is present in small enterprises, enterprises in the stagnation phase and enterprises oriented towards international markets. The impact of the laissez-faire style is as follows: (i) a negative impact is present in enterprises in the growth and maturity phase; (ii) a neutral impact is present in large enterprises, enterprises in the stagnation phase, as well as in both enterprises oriented towards international markets and enterprises oriented towards domicile markets, and (iii) a positive impact is not present in any enterprise group.

Overall conclusions are as following: (i) small enterprises are more successful financially in the presence of the democratic style and the laissez-faire style, while no leadership style has a statistically significant effect on the financial success in large enterprises; (ii) enterprises in the stagnation phase are more successful in the presence of all leadership styles, while no leadership style has a statistically significant impact on the financial success in enterprises in the growth and maturity phase; (iii) enterprises oriented towards international markets are more successful financially in the presence of the democratic style and the laissez-faire style, while no leadership style has a statistically significant impact on the financial success in enterprises oriented towards domicile markets.

\section{References}

1. Eljelly, A. M. (2004), "Liquidity-profitability tradeoff: An empirical investigation in an emerging market", International journal of commerce and management, Vol. 14, No. 2 , pp. 48-61.

2. Griffin, D. (2002). The emergence of leadership: Linking self-organization and ethics, Psychology Press, London.

3. Kang, W., Montoya, M. (2014), "The impact of product portfolio strategy on financial performance: The roles of product development and market entry decisions", Journal of Product Innovation Management, Vol. 31, No. 3, pp. 516-534.

4. Koontz, H., Weihrich, H. (1990). Essentials of Management, McGraw-Hill, New York.

5. Kovach, J. J., Hora, M., Manikas, A., Patel, P. C. (2015), "Firm performance in dynamic environments: The role of operational slack and operational scope", Journal of Operations Management, Vol. 37, pp. 1-12.

6. Miloloža, I. (2015a), "Relation of leadership and business performance: balanced scorecard perspective", Interdisciplinary Management Research IX, Ekonomski fakultet U Osijeku, Hochschule Pforzheim University, Osijek, Pforzheim, pp. 159-171. 
7. Miloloža, I. (2015b), "Impact of Leadership Style to the BusinessPerformance: Balanced Scorecard Approach", in Baćović, M., Milković, M., Pejić Bach, M., Peković, S. (Eds), Proceedings of theENTERNOVA - ENTerprise REsearch InNOVAtion Conferece, Udruga za promicanje inovacija i istraživanja u ekonomiji, Zagreb, pp. 222-227.

8. Miloloža, I. (2015c), "Leadership Differences: Internationalization, Size and Development", in Baćović, M., Milković, M., Pejić Bach, M., Peković, S. (Eds), Proceedings of theENTERNOVA - ENTerprise REsearch InNOVAtion Conferece, Udruga za promicanje inovacija i istraživanja u ekonomiji, Zagreb, pp. 339-346.

9. Niven, P. (2007). Balanced Scorecard: Korak po korak, Masmedia, Zagreb.

10. Northouse, P. G. (2012). Leadership: Theory and practice, Sage, Thousand Oaks.

11. Parast, M. M., Golmohammadi, D., Mcfadden, K. L., Miller, J. W. (2015), "Linking business strategy to service failures and financial performance: Empirical evidence from the US domestic airline industry", Journal of Operations Management, Vol. 38, pp. 14-24.

12. Parmenter, D. (2010). Key performance indicators (KPI): developing, implementing, and using winning KPIs, John Wiley \& Sons, New York.

13. Pejic Bach, M., Knežević, B., Strugar, I. (2006), "Strategic Decision Making in Human Resource Management Based on System Dynamics Model", WSEAS Transactions on Systems, Vol. 5, No. 1, pp. 285-288.

14. Pejic Bach, M., Simic, N., Merkac, M. (2013), "Forecasting Employees' Success at Work in Banking: Could Psychological Testing Be Used as the Crystal Ball?", Managing Global Transitions, Vol. 11, No. 3, pp. 283-299.

15. Rožman, M., Treven, S., Čančer, V. (2017), "Motivation and Satisfaction of Employees in the Workplace", Business systems research journal, Vol. 8, No. 2, pp. 14-25.

16. Westerfield, R. J. (2003). Fundamentals of Corporate Finance, McGraw Hill, Boston.

\section{About the author}

Asisstant Professor Ivan Miloloža, Ph.D. graduated from the Faculty of Economics and Business in Zagreb and received a Ph.D. at the Faculty of Economics in Osijek in 2015. He lived and worked abroad in the period from 1983 to 1986 (Argentina and the Netherlands). Since 1986, he has been employed by Munja, the only Croatian battery manufacturer, where he has performed virtually all management functions and is currently the CEO of the Board (since 1999). He is Assistant Professor at the Department of Dental Medicine and Health, Dean for Institutional Cooperation and Development and Chair of the Department of History of Medicine and Social Sciences. He has performed many social functions in various state bodies, associations and banks, and was a participant and guest lecturer at numerous domestic and foreign faculties and international conferences. Author can be contacted at email: ivan.miloloza@fdmz.hr. 